\title{
RELEVANT MARKET IN COMMERCIAL AVIATION OF THE EUROPEAN UNION
}

\author{
JAKUB KOCIUBIŃSKI*
}

\section{INTRODUCTION - THE AIRLINE INDUSTRY IN THE EU}

With more than 130 scheduled airlines and a network of over 450 airports air transport makes a key contribution to the European economy. Every year, more than 800 million people in the EU travel by air. ${ }^{1}$ During the summer holiday peak more than 30,000 scheduled flights take place daily. ${ }^{2}$ The industry employs more than 3 million people and contributes more than EUR 120 bn to European GDP. ${ }^{3}$

In commercial aviation there are two distinct models of transport with regard to route network organisation. These are the hub-and-spoke and point-to-point systems. The first is based on a system of large airports, hubs. In a nutshell, if a passenger wished to journey from point $\mathrm{A}$ to point $\mathrm{B}$, he or she would use a regional airline to reach the nearest hub, from which travel then continues to the hub closest to the destination. The passenger would then use a regional airline to reach that destination. ${ }^{4}$ The latter is based on an extensive network to allow connections between any of its points, any pair of cities. ${ }^{5}$ Each system has its own advantages and disadvantages

DOI: 10.2478/wrlae-2013-0037

* PhD candidate; LLM; Department of International and European Law, University of Wroclaw.

kociubinski.jakub@prawo.uni.wroc.pl

${ }^{1}$ The most recent data available are from 2008. In this year European carriers serviced 798 million passengers, which is a $0.7 \%$ increase on the previous year. Of this number, there were 170.6 million passengers $(21.4 \%)$ on the national routes, 345 million passengers (43.2\%) on the intra-European routes and 282.3 million passengers $(35.4 \%)$ on the crossborder routes. European Commission, DLR (Deutsches Zentrum für Luft- Und Raumfahrt e.V.) - Analyses of the European air transport market (Annual report 2008).

2 ibid.

${ }^{3}$ Eurostat, Key figures on Europe - 2009 Edition. On the competitiveness of the market, see also: Damien Neven, Paul Seabright, European Industrial Policy: The Airbus Case, Université de Lausanne, Ecole des HEC/DEEP 1995.

${ }^{4}$ The new Airbus A380 was designed for long-haul routes between hub-type airports, as is the fourth generation of the Boeing 747, the version 8 Intercontinental.

5 The new Boeing 787-8 Dreamliner, currently undergoing the flight testing and certification process, was designed to operate according to the point-to-point model. The direct predecessor size-wise is the Boeing 767-300 which could operate under both of these 
resulting from factors both technical and economic. A more detailed analysis of these systems lies beyond the scope of this paper, although a concise outline of them is required. ${ }^{6}$

Association of airlines into intercarrier agreements, so-called Airline Alliances, began in the 1930s. However, the first major alliance was created in 1989 between KLM (Koninkiijke Luchtvaart Maatschappij) and Northwest. ${ }^{7}$ The real boom in Airline Alliances occurred at the turn of the century. Three main factors are responsible for this phenomenon. The first was the deregulation of the airline industry in the United States in $1978 .{ }^{8}$ The second was an increase in the number of states that joined the open skies agreements, which opened their markets to foreign air carriers. ${ }^{9}$ The third decisive factor was liberalization and creation of a common market for passenger transport in the EU, begun in 1993. ${ }^{10}$

Currently, three major Airline Alliances - Star Alliance, ${ }^{11}$ Skyteam ${ }^{12}$ and Oneworld ${ }^{13}$ - control more than 70 percent of the market. ${ }^{14}$ This

models. Due to operational considerations (airport congestion, duration of flight etc.), some types of aircraft (i.e. T7-200ER, B737-900ER) could be used in both point-to-point and hub-and-spoke operations. Also, the Airbus A350XWB currently under development will operate mostly according to this model as it is being designed to compete with the Boeing Dreamliner and 777-200LR.

6 See also: Gillaume Burghouwt, Airline Network Development in Europe and its Implications for Airport Planning (Ashgate Publishing 2007).

${ }^{7}$ For a detailed analysis see also: Angela Cheng-Jui Lu, International Airline Alliances: EC Competition Law / US Antitrust Law and International Transport (Kluwer Law International 2003).

${ }^{8}$ The deregulation of 1978 removed government control over fares, routes and market entry for new airlines. The act came into force on 24/11/78 (The Airline Deregulation Act, Pub. L. 95-504, 92 Stat. 1705).

9 The Chicago Convention of 1944 provides a multilateral model in international air transport with regard to requirements for the operation of commercial carriers. There is also the US-EU open skies agreement [2007] OJ L134/4; ASEAN countries would soon sign a similar agreement. See also: Ruwantissa Abeyratne, 'Effects of United States/European Union open skies on competition' (2006) 40 Journal of World Trade 1099 and Liz Heffernan, Conor McAuilffe, 'External relations in the air transport sector: the Court of Justice and the open skies agreements' (2003) 28 European Law Review 601.

${ }^{10}$ The so-called Third Air Package includes Council Regulation (EEC) 2407/92 of 23 July 1992 on licensing of air carriers [1992] OJ L240/1, Council Regulation (EEC) 2408/92 of 23 July 1992 on access for Community air carriers to intra-Community air routes [1992] OJ L240/8 and Council Regulation (EEC) 2409/92 of 23 July 1992 on fares and rates for air services [1992] OJ L240/15. A full catalog of acts regulating air transport together with relevant decisions of the Commission, ECJ case law and analytical and statistical materials are available at the EC website: http://ec.europa.eu/transport/air/handbook/handbook_en.htm (accessed 20 December 2010). See also: George Williams, The Airline Industry and the Impact of Deregulation, (Ashgate Publishing 1993); Peter Nijkamp, 'Liberalisation of Air Transport in Europe: The Survival of the Fittest?' (1996) 3 Schweizerische Zeitschrift für Volkwirtschaft und Statistik 257; Claudio A. Piga, Maria José Gil-Moltó (eds) 'The liberalisation of the European civil aviation industry: economic and policy implications' (2007) 97 Rivista di politica economica.

${ }^{11}$ Star Alliance was founded in 1997 and has 28 member airlines (including PLL LOT). The Alliance has approximately 623.53 million passengers annually and more than 21,200 daily departures to 1,160 airports in 181 countries. In 2008 it generated approximately $\$ 151.51$ bn in profit and held around $29.3 \%$ of the global market [source: Alliance official website: www.staralliance.com; accessed 6 April 2011].

${ }^{12}$ Sky Team was founded in 2000 and has 13 member airlines. It carries approximately 384.7 million passengers annually between 898 locations. In 2008 it generated 
situation raises certain challenges in the context of the functioning of EU competition rules, and thus also for a market regulator, the European Commission. This emphasises the importance of the proper indication of relevant market since it translates directly into the effectiveness of legal instruments in ensuring uninterrupted competition on a given market. ${ }^{15}$

\section{THE NOTION AND RATIONALE OF RELEVANT MARKET IN ACQUIS COMMUNAUTAIRE}

The concept of relevant market is an important instrument of EU Competition Law especially in the field of merger control and prevention of abuse of a dominant position. Semantically, the term used for the purposes of EU Competition Law need not be consistent with its counterpart in the economy. This is due to the difference in situational context and function that both of these classifications serve. ${ }^{16}$

The key concept in identifying the product market is substitutability. ${ }^{17}$ In other words, whether one product can be replaced by another. ${ }^{18}$ Supply-side substitution relates to the possibility of turning to products that are not yet offered by particular competitors, but that would readily be offered by them in the event of a higher price of the product in question. Demand-side substitution relates to the possibility of a customer switching to alternative products that are already available on the market. ${ }^{19}$ This is an essential consideration whether other suppliers may decide to enter a new market and what costs they are therefore willing to pay. Commission Notice on the definition of the relevant market for the purposes of Community competition law pointed to two conditions, fulfilment of which would lead this potential competition to reach a decision to start operations on a new market. ${ }^{20}$ The former is the ability to start immediately on a new market while the latter relates to a lack of significant increase in cost associated with an expansion. ${ }^{21}$

From the demand-side, the price of a product, its features and availability and the terms under which it is offered should be taken on account when assessing whether it constitutes an alternative on the market. ${ }^{22}$

approximately $\$ 99.78$ bn in profit and held around $20.6 \%$ of the global market [source: Alliance official website: www.skyteam.com; accessed 6 April 2011].

13 Oneworld was founded in 1999 and has 11 member airlines. It carries 328.63 million passengers annually between 727 locations. In 2008 Alliance generated $\$ 99.78$ billion profit and held around $23.2 \%$ of the global market [source: Alliance official website: www.oneworld.com; accessed 6 April 2011].

${ }^{14}$ Cheng-Jui Lu (n 7) 9.

${ }^{15}$ For analysis of competition in the market from an economic standpoint see also: Piga, Gil-Moltó, Aguiló Pérez (n 10).

${ }^{16}$ Luc Peeperkorn, Vincent Verouden, 'The Economics of Competition' in Jonathan Faull, Ali Nikpay (eds), The EC Law of Competition (Oxford University Press 2007) 39.

17 Commission Notice on the definition of the relevant market for the purposes of Community competition law, [1997] OJ C 372/5.

18 ibid.

${ }^{19}$ Peeperkorn, Verouden (n 16) 41.

${ }^{20}$ Commission Notice (n 17).

21 ibid.

22 ibid. 
While the underlying idea is clear, in practice it is often rather difficult and sometimes impossible to make that assessment. ${ }^{23}$

The need for a framework to assess economic substitutability has led to the development of the SSNIP test (Small but Significant Non-transitory Increase in Price, sometimes called the hypothetical monopolist test). The test suggests the following line of enquiry: postulate a hypothetical small (5$10 \%$ on average) increase in the price at which the product in question is offered on the market. ${ }^{24}$ At the same time, prices of the alternative products are held constant. ${ }^{25}$ If as a result customers would switch to another product, then this alternative product must be considered a substitute. ${ }^{26}$ Thus the SSNIP test serves as a benchmark as to whether it would be profitable for a supplier (the hypothetical monopolist) to raise the price for the product concerned or not. ${ }^{27}$ Hence the relevant market from the supply-side perspective is, to quote B. Owen and S. Wildmane, 'something worth monopolizing'. ${ }^{28}$ In the absence of alternative products, the supplier having obtained a monopoly would be free to increase prices, ultimately increasing profits. $^{29}$

Geographic market is a distinguishable area in which enterprises concerned are involved in the supply and demand of products or services. The conditions of competition should be sufficiently homogenous. ${ }^{30}$ Conceptual approach to geographic market can again be based on the SSNIP test. From the supply-side this assesses the possibility of enterprises located outside a certain geographic area beginning immediate supply into that area. Demand-side substitution relates to the extent to which customers in a given geographic area are able and willing to switch to suppliers located outside this area. Therefore the geographic market will be the one in which external enterprises are unable to begin their operations swiftly and customers have an inability (are unable or unwilling) to switch to suppliers located outside the given area. ${ }^{31}$

\footnotetext{
${ }^{23}$ Peeperkorn, Verouden (n 16) 42.

${ }^{24}$ Charles Rowley, Anne Rathbone, 'Political Economy of Antitrust' in Manfred Neumann, Jürgen Weigand (eds) The International Handbook of Competition (Edward Elgar Publishing 2004) 181.

25 ibid.

26 ibid., also Peeperkorn, Verouden (n 16) 42.

27 ibid.

28 Quoted in Simon Bishop, Mike Walker, The Economics of EC Competition Law: Concepts, Application and Measurement (Sweet \& Maxwell 2002) 84.

${ }^{29}$ The lack of real competition may give a monopolist less of an incentive to invest in new ideas or consider consumer welfare. It can also be argued that even if the monopolist benefits from economies of scale, they will have little incentive to control production costs and ' $\mathrm{X}$ ' inefficiencies will mean that there will be no real cost savings. See also: Arthur Sullivan, Steven M Sheffrin, Economics: Principle in Action (Pearson/Prentice Hall 2007); Richard O Zerbe Jr, Economic Efficiency in Law and Economics (Edward Elgar Publishing 2001).

${ }^{30}$ Commission Notice (n 17). See also: Mario Monti, EC Competition Law (Cambridge University Press 2007) 139.

${ }^{31}$ It must be noted that the SSNIP test only measures competition based on price and thus cannot be considered a catch-all or fully sufficient tool for defining markets. The reliability and analytical value of the SSNIP test could be hindered by the so-called 'cellophane paradox'. This term describes incorrect reasoning regarding identification of substitutes on a given market. It may happen therefore that in using the SSNIP test the relevant market is defined too broadly, including products which are not substitutes, and thus assessment of
} 
Criteria for product market and geographic market are used to define relevant market for the purpose of EU Competition Law. This serves as a tool for an assessment of whether companies are, or will be, in a position to exercise market power. It thereby allows for a preliminary screening of cases to see whether there may be a competitive issue or not. It is especially useful in the context of antitrust analysis.

The ECJ in the Nouvelles Frontiéres and French Seamen cases stated that maritime and air transport are outside the scope of the common transport policy. ${ }^{32}$ The Court held that inclusion of these sectors in a special legal regime of transport policy would require explicit provision in the Treaties. ${ }^{33}$ As such, competition rules from part of the general rules of the Treaty apply fully in the airline industry. ${ }^{34}$

\section{MARKeT DEFINITION IN RESPECT OF SCHEDULED AIR Transport of PASSENGERS}

The point of departure for determining the relevant market in air service is pointing out the basic categories of air carriers in terms of the nature of their services, their business models and the mutual competition between them.

The first, largest and most important category is 'legacy' or 'full service network carrier' (FNSC). ${ }^{35}$ These are airlines that focus on providing a wide range of pre-flight and onboard services, including different service classes, and connecting flights. Since most FNSCs operate a hub-and-spoke model, this group of airlines are usually also referred to as hub-and-spoke airlines. ${ }^{36}$ These airlines typically have an extensive route network including long-haul intercontinental flights. Air carriers in this category carry nearly 10 million passengers annually. ${ }^{37}$

The second category is 'low-cost carrier' (LCC). These airlines focus on cost reduction in order to implement a price leadership strategy. ${ }^{38}$ They offer a so-called no-frills service (no onboard meals, no premium

the market power of a given enterprise would be incorrect. This argument calls for some caution in applying the SSNIP test. Evidence that, say, a 5\% price rise would lead to more than a $10-15 \%$ decrease in demand should not be regarded as stating that a market delimitation should be wider. See also: Massimo Motta, Competition Policy: Theory and Practice (Cambridge University Press 2005) 105.

32 Joined Cases 209/84, 210/84, 211/84, 212/84, 213/84 and 214/84, Criminal proceedings against Lucas Asjes and Others, Andrew Gray and Others, Jaques Maillot and Others, and Léo Ludwig and Others (Nouvelles Frontiéres ) [1968] ECR 1425 and Case 167/73 Commission v France (French Seamen) [1974] ECR 359.

${ }^{33}$ Nouvelles Frontiéres (n 30) paras 31, 40-42.

34 ibid. paras 32, 45. For details see Martin Stainland, Europe of the Air? The Airline Industry and European Integration (Rowman \& Littlefield Publishers 2008) 77-79.

${ }^{35}$ In most EU countries the national carrier operates as a FNSC.

${ }^{36}$ This is not entirely correct as most of the heavily hub-oriented carriers operate a hybrid model which includes a limited number of point-to-point services which do not connect with a hub.

${ }^{37}$ European Commission, DLR (n 1$) 47$.

38 See also: Ruwantissa Abeyratne, "The decision in the "Ryanair" case - the low cost carrier phenomenon' (2004) 39 European Transport Law: Journal of Laws and Economiscs 585 . 
cabins etc.). Connections, short to medium, are held generally between airports of secondary importance as they offer lower fees (ground handling etc.) ${ }^{39}$ Furthermore, serving a smaller, uncongested airport enables LCCs to maximize aircraft utilization. The use of a young and homogenous fleet of medium-sized aircraft (typically Boeing 737-800/900/NG or Airbus $319 / 320 / 321$ ) usually leads to a reduction in fuel and maintenance and, if large orders are placed at discounted prices, also capital costs. High density seating leads to lower unit costs in all categories and fixed costs (like ATC) can be distributed among more passengers. Annually, around 6 million passengers use LCC services and this number is constantly increasing. ${ }^{40}$

The third category comprises regional carriers, also called commuter airlines or feeder airlines. These generally use smaller aircraft with highdensity seating (typically CRJ700/900/1000 or Embraer E-series, although, despite the general trend of regional aircraft becoming larger, some smaller airframes are also in operation) and restrict their flight routes to a geographically limited area. Regional airlines often provide a feeder service for major air hubs. Furthermore, since these air carriers use small machines able to operate from shorter runaways, a service may travel to peripherally located areas. Regional airlines carry around one million passengers annually. ${ }^{41}$

The last category is formed by holiday or leisure carriers, often called charter airlines. ${ }^{42}$ These airlines provide non-schedule services and focus on transportation of tourists. Most holiday flights are not sold directly by the airline to the passengers, but are included in charter packages offered by tour operators. ${ }^{43}$ The operations of leisure carriers are especially widespread in northern Europe where they provide 'package holiday' services to remote leisure locations. Charter airlines carry around 800,000 passengers per year, but the business is in constant decline mainly due to competition from low-cost carriers. ${ }^{44}$

The point of departure for market definition in air transport is the socalled 'point-of-origin/point-of-destination' (O\&D) approach. According to this approach, every combination of city pairs should be considered a separate market from the passenger's point of view. In this context, large network carriers operating a hub-and-spoke system have argued that network effect should be taken into account in defining the relevant market. ${ }^{45}$ Network effect relates to the assumption that a significant proportion of passengers would use the hub for connecting flights and therefore number of routes available from a given airport should be taken into account. ${ }^{46}$

\footnotetext{
${ }^{39}$ See also: G Germà Bel, Xavier Fageda, 'Privatisation, regulation and airport pricing: an empirical analysis for Europe' (2010) 37 Journal of Regulatory Economics 142.

${ }^{40}$ European Commission, DLR (n 1$) 47$.

41 ibid.

${ }^{42}$ Nowadays many holiday flights are operated as scheduled services, albeit often seasonal.

${ }^{43}$ Monique Negnman, Maria Jaspers, Rita Wezenbeek, Joos Stragier, 'Transport', in Faull, Nikpay (n 16) 1579-1580.

44 Rigas Doganis, Flying off course. The Economics of International Airlines (3rd edn, Routledge 2002) 177-179.

${ }^{45}$ Negnman, Jaspers, Wezenbeek, Stragier (n 41) 1581-1582.

46 ibid.
} 
The Commission acknowledges that in the business model of huband-spoke carriers network competition is relevant from the supply-side perspective. ${ }^{47}$ However in the United Airlines/US Airways decision, the Commission concluded that the existence of network effect is insufficient to modify its demand-side approach. ${ }^{48}$ The Commission then argued that passengers are primarily concerned with getting from point $\mathrm{A}$ to point $\mathrm{B}$ and in the event of a price increase on a given route as a result of having a dominant carrier, it would be irrelevant to them whether this operator has an extensive network of connections where it competes with the other airlines. $^{49}$

The demand-side approach preferred by the Commission does not mean that it ignores the network effect. In fact in the Air France/KLM case the Commission implicitly indicated that demand for air services can also by generated by the existence of network effect, especially in the case of corporate customers. ${ }^{50}$

Furthermore, when defining the relevant market the Commission usually takes into account the profile of the passengers. Two main categories can be distinguished there. Time-sensitive passengers focus mainly on flexibility. ${ }^{51}$ The primary criteria according to which they select an airline are number of daily flights, the location of the airport, convenience of departure and arrival time and opportunity to rescheduled their reservation at short notice. The non-time-sensitive passengers are in general more price-oriented. ${ }^{52}$ They require less flexibility and are willing to accept longer journey time. This classification largely coincides with the distinction between business and leisure travellers. ${ }^{53}$

\section{Alternative Transport PossibiLities}

Having identified the relevant O\&D market, it is necessary to consider the different transport possibilities which could be regarded as substitutable for the services provided by the air carriers in question. Whether the potential alternatives are viable depends on a multitude of factors. Such assessment must therefore factor in the specific characteristics of each individual route. ${ }^{54}$

For most of the intra-European routes the distance that passengers are willing to travel to reach a departure airport would be rather small. However, for long-haul flights the radius of an airport catchment area would

\footnotetext{
47 ibid. 1582-1583.

${ }^{48}$ United Airlines/US Airways (Case M.2041) [2001] OJ C270/131.

49 ibid.

${ }^{50}$ Air France/KLM (Case M.3280) [2004] OJ C60/5, paras 10-16 and 130-135.

${ }^{51}$ Air France/Alitalia (COMP/A.38284/D2) Commission Decision 2004/841/EC [2004] OJ L362/17, para 11.

52 ibid.

53 KLM/Alitalia (Case JV.19) [1999] OJ C184, para 21; SAS Maersk (Case COMP.D.2.37.444) [2001] OJ L265/15, para 30; Air France/Alitalia (n 51) paras 41, 4446; United Airlines/US Airways (n 48) para 18.

54 Trevor Soames, 'EC competition Law and Aviation: „,caution optimism spreading its wings"” (2006) 27 European Competition Law Review 599.
} 
grow significantly. ${ }^{55}$ Of course, at the end of the day, whether an adjacent airport would provide a suitable alternative depends on a number of factors, such as convenience in access to the airport, duration of the journey, frequency of service and service features (price etc.).

Another factor is the competition from low-cost carriers. Traditional carriers have over recent years faced increased competition from these airlines, so this factor is gaining in prominence. ${ }^{56}$ For example, in 2008 the four largest low-cost carriers in Europe - Ryanair, easyJet, Air Berlin and Flybe - performed respectively 7,546, 6,382, 4,171 and 3,044 flights weekly. For comparison, the two largest European flag carriers - Lufthansa and Air France - offered 10,000-12,000 flights every week. The third and fourth largest national carriers- Iberia and British Airways (recently merged) - conducted 5,000-6,000 flights weekly. ${ }^{57}$ The service offered by the low-cost carriers will to a lesser extent provide an alternative for timesensitive customers, but for the non-time-sensitive passengers it is certainly a competitive offer. ${ }^{58}$

Charter flights are not considered to be sufficiently substitutable for scheduled flights, and certainly not for time-sensitive passengers and flexibility-focused passengers, mainly due to the low frequency of flights. ${ }^{59}$ However, in its decision in British Airways/SN Brussels airlines the Commission did not rule out that under certain circumstances, nonscheduled services may be a substitute for non-time-sensitive passengers. ${ }^{60}$

Indirect flights may provide a convenient alternative to direct services, especially in the case of one-stop services. ${ }^{61}$ The decisive factors are the duration of a flight, the connection time, flight schedules and price. Generally, indirect flights are more likely to be considered an alternative to medium- to long-haul flights. ${ }^{62}$

Alternative modes of transport, such as high-speed trains and road transport, can to a certain extent provide a suitable alternative for air transport. ${ }^{63}$ The rule of a thumb when comparing total travelling time of a flight service and an alternative mode of transport is to add two hours to the total flight time so as to factor in time required to reach the airport and airport procedures (check-in, luggage reclaim etc.) ${ }^{64}$ For example, on the basis of this calculation the Commission concluded that the rail link from Brussels to London operated by the high-speed trains of the Eurostar line is a viable alternative to the scheduled air service. Generally, for timesensitive passengers an alternative means of transport may be a possible alternative only where travel time is not significantly longer. However, for

\footnotetext{
${ }^{55}$ Negnman, Jaspers, Wezenbeek, Stragier (n 41) 1580.

${ }^{56}$ In context of Case T-196/04 Ryanair Ltd v Commission [2008] II-3643. See. Ruwantissa Abeyratne, 'The Decision in the „Ryanair” Case - The Low Cost Carrier Phenomenon' (2004) 39 European Transport Law: Journal of Laws and Economics 585.

${ }^{57}$ European Commission, DLR, (n 1$) 47$.

${ }^{58}$ Air France/Alitalia (n 51) para 54-55.

${ }^{59}$ KLM/Alitalia (n 53) paras 55-56; Air France/Alitalia (n 51) para 56.

${ }^{60}$ British Airways/SN Brussels Airways (Case C.38.477) [2002] OJ C306/5 paras 29-32.

${ }^{61}$ Negnman, Jaspers, Wezenbeek, Stragier (n 41) 1580.

62 ibid.

63 ibid.

${ }^{64}$ British Airways/SN Brussels Airways (n 60) paras 18-21.
} 
price-minded travellers travel time might be less important, and thus for them this option is more attractive. ${ }^{65}$

\section{MARKET DEFINITION IN RESPECT OF AIR TRANSPORT OF CARGO}

A different methodology is applicable when defining the relevant market in the case of the air cargo transport. ${ }^{66}$ Unlike passengers, freight can be carried on economically acceptable terms with a higher number of stopovers. This is due to the fact that time is not such a crucial factor in transport of freight, except in the case of perishable goods, the range of alternative methods is thus broader. The relevant market in air freight transport is therefore in principle wider than in transport of passengers. For intra-European routes the relevant market would be Europe-wide, including road transport and, to a lesser extent, transport by rail. ${ }^{67}$ In the event that one of the points of origin or destination is located outside the EU the relevant market would cover the whole continent at least for those routes where local infrastructure allows onward connections. ${ }^{68}$

\section{CONCLUSION}

Analysis of the factors contributing to the definition of the relevant market in the airline industry draws attention to the practical implications of such a definition. This merely recalls the fact that market definition is not a goal in itself, but an intermediate step for structuring an analysis. The aim of market definition is to analyze economic substitutability of products in a structured way, potentially helping reveal infringement of EU law. ${ }^{69}$ If this happens, the Commission, whose primary function is to act as guardian of the Treaties, shall respond appropriately to prevent actual or potential distortions of the market created by 'concerted practices', abuse of dominant position and mergers. ${ }^{70}$ Every competition case involves extensive forensic work encompassing the identification and assessment of market and analysis of impact (actual or potential) of practices or proposed actions by one or more airlines. ${ }^{71}$ Adequate definition of a relevant market which contributes to the effectiveness of regulatory actions is therefore essential for

\footnotetext{
${ }^{65}$ Negnman, Jaspers, Wezenbeek, Stragier (n 41) 1581.

66 ibid.

${ }^{67}$ Lufthansa/SAS, (Case COMP/D-2/36.201, 36.076, 36.078C) [2002] OJ C 264/5 para 33.

${ }^{68} \mathrm{KLM} /$ Alitalia (n 53) paras 21-23.

${ }^{69}$ See also Robert Strivens, Elizabeth Weightman, 'The Air Transport Sector and the EEC Competition Rules in the Light of Ahmed Saeed Case' (1989) 10 European Competition Law Review 557.

${ }^{70}$ See also David R Little, 'The case for a primary punishment rationale in EC anti-cartel enforcement' (2009) 5 European Competition Journal 37.

${ }^{71}$ Stainland (n 34) 236.
} 
maintaining the overall competitiveness of the market and ensuring respect for passenger rights. ${ }^{72}$

All of this boils down still to the question of how successful the Commission has been in protecting and promoting opportunities for competition. In other words, whether competition policy has succeeded or failed. The result of the Commission approach seems to be a somewhat ambiguous policy. Mario Monti, when competition commissioner, expressed the opinion that the Commission should "not stand in the way of consolidation provided competition concerns, when they exist, are addressed in a satisfactory way'. ${ }^{73}$ On the other hand Michael Aryal, DGTREN's director for air transport, remarked: 'We fail consolidation. We support consolidation. ... Of course we cannot support this at the cost of competition" ${ }^{74}$ It seems then that the Commission is torn between two conflicting goals, competition and consolidation. The consolidationapproval approach reflects the long-established belief that European industry needs all the competitive edge it can obtain in the face of American challenges. ${ }^{75}$ In this case it is unclear why the Ryanair-Aer Lingus merger was quashed. We can therefore observe a tension between competitiveness (on a global scale) and competition, and this raises the question of the extent of consumer choice.

\footnotetext{
${ }^{72}$ For detailed analysis of passenger rights see: Morten Broberg, 'Air Passengers' rights in the European Union: The air carriers obligations vis-à-vis their passengers under Regulation 261/2004' (2009) 7 The Journal of Business Law 727.

${ }^{73}$ Commission press release IP/04/469 Commission approves alliance between Air France and Alitalia 07/04/2004.

74 The opinion relates to the Air France/KLM merger. Quoted in Stainland (n 34) 237.

${ }^{75}$ It should be taken into account that the airline industry in the United States is undergoing serious concentration. It is enough to mention the largest merger in air transport history, United Airlines-Continental Airlines (including all subsidiaries).
} 